\title{
PENTINGNYA PERLINDUNGAN HUKUM PATEN WARGA NEGARA ASING DI WILAYAH INDONESIA GUNA MENINGKATKAN INVESTASI ASING
}

\author{
Syafrida \\ Fakultas Hukum Universitas Tama Jagakarsa \\ Email: Syafrida_01@yahoo.com
}

\begin{abstract}
ABSTRAK
Hak paten merupakan salah satu ruang lingkup Hak Kekayaan Intelektual. Hak paten diberikan kepada seseorang atau sekumpulan orang penemuannya di bidang tekonologi yang mempunyai posisi yang sangat penting dan strategis untuk mendukung. Hak paten merupakan hak eksklusif yang diberikan oleh negara kepada inventor atas invensinya di bidang teknologi dan orang yang mendapat hak darinya. Paten sangat dibutuhkan untuk menunjang berbagai kehidupan dalam masyarakat. Undang-undang Hak Paten Nomor 13 tahun 2016 tidak hanya memberikan perlindungan terhadap paten warganegara Indonesia tapi juga memberikan perlindungan hokum terhadap paten warga negara asing di Indonesia. Perlindungan hokum itu diberikan guna meningkatkan investasi di Indonesia dan menigkatkan kreatifitas inventor atas invensi berguna bagi perkembangan dalam masyarakat. Untuk memberi rasa aman, nyaman kepada Inventor asing maka negara memberikan perlindungan hukum invensi paten warga negara asing yang dilaksanakan di Indonesia. Paten yang dilindungi adalah paten telah didaftar yang penemuan di bidang teknologi merupakan posisi penting untuk mendukung pembangunan ekonomi masyarakat guna memajukan bangsa dan negara.
\end{abstract}

Kata Kunci: Hak Paten, perlindungan hukum ,produk impor

Abstract

He patent is one of the scope of intellectual property rights. A patent is granted to a person or a group of people its discovery in the field of technology which has a very important position and strategically to support. A patent is an exclusive right granted by the State to the inventor's top invensinya in the field of technology and the people who got the rights to it. The patent is necessary to support the variety of life in the community. Patent Law No. 13 year 2016 do not only provide protection against patent citizens of Indonesia but also provides protection against patent law foreign citizens in Indonesia. The protection of the law was given in order to increase investment in Indonesia and would kereatifitas inventor's top invention useful for developments in society. To give a sense of security, convenient to the Inventor's foreign country then provide protection invention patenting law foreign citizens in Indonesia.

Keywords: patents, law, protection of imported products 


\section{PENDAHULUAN}

Kemajuan di bidang perdagangan dan bisnis seiring dengan perkembangan teknologi sebagai isyarat telah terjadi perkembangan masyarakat sederhana kearah masyarakat modern. Perkembangan bisnis dan perdagangan tidak dapat dilepaskan dari perkembangan teknologi menjadi penting bagi inventor atau penemuannya dibidang teknologi untuk mendaftarkan temuannya untuk mendapatkan hak paten agar tidak di klaim oleh pihak lain sebagai temuannya.

Hak Paten merupakan salah satu ruang lingkup hak kekayaan intelektual. Hak kekayaan intelektual termasuk benda. Benda adalah segala sesuatu yang dapat dihaki oleh orang. ${ }^{1}$ Berdasarkan Pasal 503 KUHPerdata menyatakan: “ Tiap-tiap benda adalah bertubuh dan tidak bertubuh". ${ }^{2}$ Benda tidak bertubuh sama pengertiannya sama dengan benda tidak berweujud dan benda bertubuh sama pengertiannya dengan benda berwujud.Paten sebagai hak ke Mengacu pada Pasal 503 KUHPerdata, maka Hak Kekayaan Inteltual (HKI) termasuk benda tidak bertubuh atau benda tidak berwujud. Hak Paten sebagai benda bergerak tidak bertubuh sama dengan hak kebendaan pada umumnnya dapat dimiki, dialihkan kepada pihak lain dan dijadikan jaminan dengan fidusia.

Pasal 499 KUHPerdata menyatakan, menurut paham undang-undang yang dinamakan kebendaan adalah" tiap-tiap barang atau tiap- tiap hak, yang dapat dikuasai oleh hak milik". ${ }^{3}$ Mengaju pada Pasal 499 KUHPerdata tersebut Hak Paten sebagai salah satu Hak Kekayaan Intelektual termasuk hak kebendaan termasuk benda bergerak tidak bertubuh yang dapat dijadikan objek hak milik dan dapat dipidahkan oleh pemegang hak paten kepada pihak lain, sehingga pihak lain tersebut mendapat keuantungan secara ekonomis yang sebelumnya diikat dengan perjanjian lisensi. Pemegang hak paten yang telah mengalihkan haknya kepada pihak lain sehingga pihak lain mendapat keuntungan ekonomi, sebagi kontra prestasinya pihak lain yang menerima peralihan hak paten tersebut harus membayar royalti kepada pemegang hak paten sesuai dengan yang diperjanjikan.

\footnotetext{
${ }^{1}$ Subekti, Pokok-Pokok Hukum Perdata, Cetakan ke-XX, Bandung: Intermasa, Bandung, 1982), hlm. 60.

${ }^{2}$ Subekti dan R Tjiprosudibio, Kitab Undang-Undang-Undang Hukum Perdata, Cetakan ke-10 , ( Jakarta: Pradnya Paramita,, 2003), hlm. 157

${ }^{3}$ Ibid, hlm. 157.
} 
Berdasarkan Pasal 503 dan 499 KUHPerdata dapat diambil pengertian, bahwa Hak Kekayaan Intelektual yang selanjutnya disebut HKI termasuk benda bergerak tidak berwujd dapat dijadikan objek hak milik, dialihkan dan dimanfaatkan oleh pihak lain melalui perjanjian lisensi. Hak paten adalah hak kebendaan immaterial dapat dijadikan jaminan dengan Fidusia, sehingga Hak Peten termasuk hak kebendaan yang bersifat memberikan jaminan.

Hak paten sebagai salah satu ruang lingkup Hak Kekayaan Intelektual hanya diberikan oleh negara kepada inventor di bidang teknologi yang mempunyai peranan strategis dan penting untuk mendukung pembangunan dan memajukan kesejahteraan umum. Karya di bidang teknologi yang dihasilkan oleh inventor adalah termasuk kekayaan bagi pemiliknya yang dapat dinikmati, dialihkan, dimanfaatkan atau digunakan pihak lain, sehingga pihak lain itu tersebut memperoleh manfaat ekonomi dari hak paten yang diikat dalam suatu perjanjian lisensi.

Perkembangan teknologi yang sangat pesat diberbagai bidang dewasa ini diperlukan peningkatan perlindungan hukum terhadap pemegang hak paten. Peningkatan Perlindungan Hak Paten sebagai salah satu hak kekayaan inteletual, karena hak paten berperan penting untuk memajukan, mensejahteraan masyarakat, bangsa dan negara. Perlindungan terhadap pemegang hap paten sebagai hak eksklusif diberikan oleh negara kepada inventor di bidang teknologi yang mempunyai peranan strategis dalam mendukung pembangunan bangsa dan memajukan kesejahteraan umum. ${ }^{4}$

Perlindungan hukum terhadap pemegang paten bertujuan untuk memotivasi inventor dalam menigkatkan hasil karyanya baik secara kuantitas maupun kualitas untuk mendorong kesejahteraan bangsa dan negara serta menciptakan iklim usaha yang sehat. Paten yang diberikan perlindungan bukan hanya terhadap temuan dibidang teknologi, tapi juga hak eksklusif yang melekat pada pemilik atau pemegang hak paten, sehingga apabila pihak lain yang yang menerima peralihan berkeinginan untuk mendapat manfaat ekonomi mengunakan

\footnotetext{
${ }^{4}$ Pertimbangan huruf a Undang-Undang Nomor 13 tahun 2016 tentang Paten
} 
hak paten tersebut wajib memperoleh lisensi (izin) dari pemiliknya atau pemegangnya. $^{5}$

Pasal 1 angka 1 Undang Nomor 13 Tahun 2016, paten adalah hak eksklusif yang diberikan oleh negara kepada inventor atas invensinya di bidang teknologi untuk jangka waktu tertentu melaksanakan sendiri invensinya tersebut atau memberikan persetujuan kepada pihak lain untuk melaksanakannya. ${ }^{6}$ Berdasarkan Pasal 1 angka (1) Undang-undang Nomor 13 Tahun 2016 tentang Paten merupakan hak Eksklusif atau hak istimewa yang diberikan negara kepada pemegang hak paten, Negara memberikan hak eksklusif kepada pemegang hak paten, karena hak paten merupakan penemuan dibidang teknologi yang mempunyai peran strategis dan penting untuk memajukan pembangunan guna mensejahteraan masyarakat. Hak paten tersebut dapat dilaksanakan sendiri oleh pemegangnya atau dialihkan kepada pihak lain.

Banyak proses produk tidak lepas dari peran teknologi. Dengan teknologi produk barang dan/ atau jasa yang dihasilkan lebih cepat dan bekwalitas. Salah satu ciri negara maju adalah kemajuan dan perkembangan teknologi, seperti Amerika serikat, Jepang, Korea Inggiris, Perancis, Jerman dan lainnya. Kemajuan teknologi yang dimliki oleh negara maju tersebut menyebabkan dalam sektor kehidupan masyarakat tenaga manusia digantikan oleh teknologi.

Perlindungan hak paten diberikan tidak hanya melindungi inventor paten nasional tetapi juga memberikan perlindungan Inventor Paten Asing di wilayah Indonesia. Perlindungan Inventor paten juga memotivasi inventor lain untuk menghasilkan karya-karya bidang teknologi untuk memajukan masyarakat dan bangsa. Aspek kehidupan masyarakat dewasa ini banyak sekali mengunakan sarana teknologi, dengan hadirnya teknologi dalam kehidupan masyarakat akan memberikan kemudahan dan kecepatan bagi masyarakat dalam mendapat informasi dalam rangka memenuhi kebutuhan masyarakat.

Hak paten tidak hanya mempunyai nilai ekonomi bagi penemunya, tetapi juga memberi keuntungan ekonomi bagi orang lain yang mengunakannya berdasarkan perjanjian dengan pemegang paten, sehingga syarat sah perjanjian

\footnotetext{
${ }^{5}$ Abdulkadir Muhammad, Kajian Hukum Ekonomi Hak Kekayaan Intelektual, (Bandung: PT Citra Aditya Bakti 2007, hlm. 3.

${ }^{6}$ Undang-Undang Nomor 13 tahun 2006 tentang Paten
} 
juga berlaku dalam hak paten. Hak paten mempunyai peran yang sangat penting dan strategis untuk pembangunan ekonomi dan memajukan masyarakat dan bangsa. Peran penting dan staregis dari hak paten, negara memberikan perlindungan eksekutif kepada pemegangnya untuk mengunakannya sendiri atau memberikan hak kepada orang lain untuk menikmati atau mendapat keuntungan ekonomis berdasarkan perjanjian. Perlindungan hukum terhadap hak paten diberikan setelah dilakukan pendaftaran ada Dirjen HKI pada Kementerian Hukum dan Ham.

Undang-Undang paten Indonesia tidak hanya memberikan perlindungan hukum terhadap paten nasional, tetapi juga memberikan juga memberi perlindungan hukum paten warga negara asing yang pendaftaranya dilakukan di wilayah Indonesia, tapi juga melindung paten warga negara asing yang didaftarkan di Indoensia. Berdasarkan ini penulis tertarik untuk menulis tentang Pentingnya Perlindungan Paten warga negara asing di wilayah Indoensia dalam meningkatkan investasi asing di Indonesia.

Metode penelitian yang digunakan dalam penulisan ini adalah adalah penelitian Kepustakaan dengan mengunakan data sekunder berupa bahan hukum primer, bahan sekunder. Bahan hukum primer berupa peraturan perundangundangan yang berlaitan dengan hukum perjanjian, HKI, hak paten, Bahan sekunder berupa buku-buku yang berkaitan dengan Hukum Perdata, Hukum Perjanjian, Hukum Ekonomi, Hak Kekayaan Intelektual khususnya berkaitan dengan Hak Paten.

Metode penelitian yang digunakan adalah penelitian undang-undang (statute approach) dilakukan dengan menelaah semua undang-undang yang bersangkut paut dengan hukum kekayaan intelektual khususnya berkaitan dengan hak paten. Pendekatan undang-undang membuka kesempatan untuk mempelajari konsistensi antara suatu undang-undang dengan undang lainnya atau undangundang dengan Undang-Undang Dasar. Hasil telaah untuk memecahkan isu yang sedang dihadapi. ${ }^{7}$

Data yang diperoleh dalam melakukan penelitian adalah data yang lansung diperoleh dari masyarakat disebut dengan data primer. Sedangkan data

${ }^{7}$ Peter Mahmod Marzuki, Penelitian Hukum, Cetakan Kesembilan, (Jakarta:Prenadamedia Group), 2014, hal 138 
Sekunder berupa dokumen resmi, buku-buku hasil penelitian berwujud buku harian laporan. ${ }^{8}$ Bahan hukum tertier berupa kamus-kamus yang digunakan menjelaskan istilah -istilah dan pengertian-pengertian berkaitan dengan hak paten.

Data yang diperoleh dari hasil penelitian Kepustakaaan berupa bahan hukum primer, bahan hukum sekunder dan bahan hukum tertier. Bahan -bahan hukum tersebut selanjutnya dijadikan pisau analisis untuk membahas apa yang menjadi permasalah dalam penulisan tulisan ini.

\section{PEMBAHASAN}

Paten sebagai salah satu hak kekayaan intelektual merupakan bagian dari benda tidak berwujud (benda Immateril). Pengertian benda secara yuridis adalah segala sesuatu yang dapat menjadi objek hak. ${ }^{9}$ Yang dapat menjadi objek hak tidak hanya benda berwujud tapi juga benda tidak berwujud. Hak paten adalah benda tidak berwujud dapat dialihkan kepada pihak lain dan dapat dijadikan jaminan Fidusia.

Hak paten merpakan hak kekayaan intelektual yang diberikan oleh negara kepada kepada inventor atas hasil invensinya di bidang teknologi yang mempunyai peranan strategis dan mendukung pembangunan bangsa dan memajukan kesejahteraan umu. Perkembangan teknologi yang sangat pesat dewasa ini dalam berbagai bidang diperlikan peningkatan perlindungan terhadap bagi inventor dan pemegang paten. Perlindungan paten diperlukan untuk memotivasi para inventor untuk meningkatkan hasil karya baik secara kuantitas maupun secara kualitas untuk mendorong kesejahteraan bangsa dan negara.

Berdasarkan Pasal Pasal 1 angka 1 tersebut diatas hak eksklusif diberikan negara kepada kepada inventor tehadap invensinya di bidang teknologi. Inventor adalah seorang atau beberapa orang yang secara bersama-sama melaksanakan ide yang dituangkan dalam kegiatan yang menghasilkan invensi. ${ }^{10}$ Sedangkan yang dimaksud dengan invensi adalah ide inventor yang dituangkan dalam suatu

\footnotetext{
${ }^{8}$ Soejono Soekanto, Pengantar Penelitian Hukum, Cetakan Ketiga,(Jakarta: UI-Press), 1986, hal 11-12.

9 Ok Saidin,, Aspek Hukum Hak Kekayaan Intelktual (Intelectual Property Rights), (Jakarta: PT Raja Grafindo Persada, , 2013), hlm. 223.

${ }^{10}$ Indonesia, Undang-undang Nomor 12 Tahun 2016 tentang Paten, Pasal 1 angka 3
} 
kegiatan pemecahan masalah yang spesifik di bidang teknologi berupa produk, proses atau penyempurnaan dan pengembangan produk atau proses. ${ }^{11}$

Dalam Undang-Undang Nomor 13 tahun 2016 tentang Paten terdapat istilah invensi dan inventor. Invensi adalah ide inventor yang dituangkan dalam suatu kegiatan pemecahan masalah yang spesifik di bidang teknologi berupa produk atau proses atau penyempurnaan dan pengembangan produk atau proses (Pasal 1 angka 2). Invensi dapat dilaksanakan sendiri oleh invenstor atau dialihkan kepada pihak lain. Inventor adalah seseorang atau beberapa orang secara bersamasama melaksanakan ide ke dalam kegiatan yang menghasilkan invensi (Pasal langka 3). Berdasarkan Pasal 1 angka (3), bahwa dapat dihasilkan oleh orang perorangan atau secara bersama-sama.

Hak paten bersifat eksklusif sebab hanya inventor yang menghasilkan invensi saja yang diberikan hak paten, dapat melaksanakan sendiri invensinya tersebut atau memberi persetujuan kepada pihak lain untuk melaksanakannya. ${ }^{12}$ Hak Eksklusif yang diberikan oleh negara kepada pemegang hak paten atas temuannya atau invensi yang temuannya di bidang teknologi termasuk proses yang digunakan dalam proses produksi yang mempunyai posisi yang strategis untuk mensejahterakan masyarakat bangsa dan negara.

\section{Objek Paten}

Objek paten adalah termasuk benda yaitu benda tak berwujud (imnaterial) yang merupakan bagian hak kekayaan industri. Maksudnya temuan di bidang paten merupakan karya seseorang atau secara bersama yang digunakan proses industri. Hak paten sebagai hak kebendaan yang dapat dijadikan jaminan dengan fidusi, juga dapat dilaihkan kepada pihak lain karena, pewarisan, hibah, wasiat, perjanjian tertulis dan sebab lain yang dibenarkan oleh Undang-Undang. ${ }^{13}$

Jadi Hak Paten berkembang pada negara yang maju secara industri dan teknologi yang dapat mengubah kehidupan masyarakat. Pada negara maju dan masyarakat modern tidak dapat dilepaskan aktifitas dengan mengunakan perangkat-perangkat di bidang teknologi. Kehadiran paten menjadi penting huntuk

\footnotetext{
${ }^{11}$ Indonesia, undang-undang Nomor 13 Tahun 2016 tentang Paten.

12. Ibid

13 Abdulkadir Muhammad, Hukum Ekonomi Hak Keayaan Intelektual, cetakan ke-2, (Bandung: PT Citra Aditya Bakti), 2007, hal 206.
} 
menunjang aktifikata masyarakat, modern pada negara-negara maju dan bagi negara yang sedang berkembang seperti Indonesia, paten sangat dibutuhkan, untuk mengolah bahan baku yang banyak tersedia di bumi Indonesia yang kemudian diolah menjadi bahan jadi yang memberi nilai secara ekonomi kepada masyarakat dan bangsa. Indonesia sebagai negara sedang berkembang yang kaya akan sumber daya alam dan sumber daya manusia yang banyak belum mampu untuk mengolah sumber daya alamnya yang disebabkan oleh belum majunya teknologi. Oleh sebab itu untuk mengolah bahan baku tersebut diperlukan teknologi, karena Sumber daya manusia yang masih terbatas ahli teknologinya menyebabkan negara kita msih membutuhkan dan tergantung pada teknologi yang dimiliki oleh negara asing terutama negara maju seperti Jepang, Korea, Cina dan Amerika.

Berkaitan Invensi paten warga negara asing yang melakukan investasi di negara Indonesia sangat kita butuhkan untuk mengolah bahan baku untuk menjadi bahan jasi. Undang Undang tentang paten memberikan perlindungan hukum paten tidak hanya memberikan perlindungan hukum kepada paten warga negara Indonesia tapi juga memberi perlindungan hukum terhadap paten warga negara asing yang melakukan kegiatan berinvestasinya di Indonesia. Untuk memberikan rasa aman, nyaman kepada Investor asing dalam menjalankan investasinya dalam wilayah Indonesia, maka negara kita memberikan perlindungan paten warga negara asing yang penemuannya di wilayah Indonesia untuk di daftarkan di Indonesia.

Paten mempunyai objek dari temuan atau invensi atau invention di bidang teknologi yang secara praktis dapat digunakan dalam bidang perindustrian. Yang dimaksud dengan industri adalah industri dalam arti seluas-luasnya termasuk didalamnnya hasil perkembangan teknologi dalam bidang industri pertanian, industri bidang peternakan dan industri bidang pendidikan. ${ }^{14}$ Berdasarkan pasal 5 Invensi yang dapat diberikan adalah Invensi dianggap baru yang dapat diterapkan dalam industri dan tidak sama dengan teknologi yang diungkapan sebelumnya yang telah diumumkan di Indonesia atau diluar Indonesia dalam suatu tulisan,

\footnotetext{
${ }^{14}$ Ibid, hlm. 230
} 
uraian lisan atau melalui peragaan, penggunaan atau dengan cara lain yang memungkinkan seorang ahli untuk melaksanakan invensi tersebut.

Invensi yang dapat diberikan paten merupakan tekonogi yang telah diumumkan di Indonesia atau diluar Indonesi melalui tulisan, peragaan, penggunaan atau dengan cara lain yang memungkinkan ahli untuk melaksananakn invensi. Jadi bagi Investor asing yang menjalankan kegiatan investasinya di Indonesia negara memberikan perlindungan hukum kepada inventor asing untuk menjalankan invensinya dalam Indonesia dan negara memberikan perlindungan sama dengan perlindungan hokum terhadap inventor dalam negeri. Lingkup perlindungan paten berdasarkan Pasal 2 Undang-Undang Nomor 13 Tahun 2016 meliputi:

a.Paten

b.Paten sederhana

Perlindungan hkum paten yang diberikan berdasarkan Pasal 2 terebut diatas dapat dibedakan paten dan paten sederhana. Paten yang dimaksud Pasal 2 huruf (a) adalah untuk invensi yang baru yang dapat diterapkan dalam industri. Sedangkan yang dimaksud dengan paten sederhana diberikan untuk invensi produk baru, pengembangan dari produk atau proses yang ada yang dapat diterapkan dalam industry. Tidak semua invensi dapat diberikan hak paten. Berdasarkan Pasal 4, invensi tidak dapat diberikan paten mencakup:

a.kreasi estetika

b.skema

c.aturan atau metode yang hanya berisi program computer

d.persentase mengenai sutu informasi

e.temua berupa:

1. pengunaan baru untuk produk yang sudah ada/ dikenal

2. bentuk baru dari senyawa yang sudah ada tidak menghasilkan penigkatan kasiat bermakna dan perbedaan struktur kimia yang ada.

Sedangkan invensi yang dapat diberikan paten adalah berdasarkan Pasal 5 adalah : invensi yang dianggap baru yang tidak sama dengan teknologi yang diungkapan sebelumnya. Teknologi tersebut telah diumumkan di Indonesia atau di luar Indonesia dalam bentuk tulisan, uraian lisan, peragaan atau dengan cara lain 
yang memungkinkan ahli untuk melaksanakan invensinya sebelum tanggal penerimaan, tanggal prioritas iika diajukan dengan hak prioritas. Teknologi yang diungkapan dapat berupa dokumen permohonan yang diajukan di Indonesia

Berdasarkan Pasal 2,4 dan 5 tersebut diatas tidak semua invensi dapat diberikan paten. Invensi yang dapat diberikan paten adalah invensi yang merupakan penemuan baru atau adanya hal-hak kebaharuan pada invensi yang belum pernah ada sebelumnnya baik berupa produk atau berupa proses yang membawa perubahan yang baru dari produk atau dari proses yang ada. Invensi yang dapat diberikan paten adalah invensi yang belum pernah dipublikasikan baik secara nasional maupun internasional. Jadi syarat invensi yang dapat diberikan paten adalah dalam bidang teknologi digunakan dalam proses industri yang mengandung kebaharuan yang mempunyai peran yang sangat penting dan strategis untuk memajukan dan mensejahterakan masyarakat dan bangsa.

Sabjek yang bisa dipatenkan antara lain, teknologi dalam bidang komunikasi yang berkembang sangat pesat saat ini, seperti handphone dengan berbagi merek yang mempuyai keistimewaan dan membedakan satu sama lain dapat dipatenkan dapat berupa proses, mesin, barang berupa perangkat elektronik dan dapat juga dipatenkan berupa metode bisnis yang menghasilkan hal-hal yang baru yang belum ada sebelumnnya yang membawa perubahan kemajuan kepada masyarakat dan bangsa ${ }^{15}$.

Contoh hak paten dari beberapa perusaah teknologi terbesar di dunia antara lain hak paten layar sentuh (Touch Schren) yang bekerja dengan adanya sentuhan layar dengan mengunakan jari atau pene digital. Hampir semua handphone sekarang ini mengunakan Touch Shren yang penemunya adalah George Samuel yang berasal dari Amerika pada tanggal 7 Oktober $1975{ }^{16}$

\section{Subjek Paten}

Mengenai subjek paten diatur dalam Pasal 10-13 Undang-Undang Nomor 13 Tahun 2016 tentang Paten. Pihak yang berhak memperoleh paten adalah inventor atau pihak lain yang menerima lebih lanjut. Invensi dapat dihasilkan

\footnotetext{
${ }^{15}$ http://berinovasi.com/2017/10/17/apa-saja-contoh-hak-paten, diakses tanggal 31 Maret 2019

${ }^{16}$ Ibid.
} 
secara bersama-sama oleh inventor yang pertama kali mengajukan permohonan. Invensi dapat dihasilkan oleh inventor dalam hubungan kerja, sebagai pemegang patennya adalah perusahaan, kecuali diperjanjikan lain. Begitu karyawan yang bekerja mengunakan fasilitas kantor, maka pemegang patennya adalah perusahaan, kecuali diperjanjikan lain. Walalupun pemegang paten adalah perusahaan tidak menghapuskan nama penemu invensi pada sertifikat hak paten.

Invensi yang dihasilakan karyawan pada yang bekarja pada suatu perusahaan berhak untuk mendapatkan imbalan dari perusahaan berdasarkan perjanjian dengan memperhatikan manfaat ekonomi dari invensi. Imbalan yang diterima invensi dapat dibayar tertentu atau sekaligus dengan dengan hadiah atau bonus, atau Bentuk lain yang disepakati para pihak. Jika tidak terdapat kesesuai mengenai cara perhitungan dan penetapan besarnya imbalan, para pihak dapat mengajukan gugatan ke pengadilan niaga.

Selanjutnya berdasarkan Pasal 13 menyatakan, pemegang paten atas invensi yang dihasilkan inventor dalam hubungan dinas dengan instansi pemerintah adalah instansi pemerintah dan inventor kecuali dperjanjikan lain. Apabila perusahaan sebagai pemegang paten yang dihasilkan oleh perusahannya tidak dapat melaksanakan patennya, maka inventor atas persetujuan pemegang patennya dapat melaksakan patennya dengan pihak ketiga. Setelah paten dikomersilkan inventor, maka inventor yang menghasilkan invensi dalam hubungan dinas dengan instansi pemerintah berhak mendapatkan imbalan atas paten yang dihasilkan yang termasuk penerimaan negara bukan pajak. Inventor yang telah memindahkan invensi kepada pihak lain berhak atas royalti.

\section{Perlindungan Hak paten}

Perlindungan terhadap hak paten akan mempercepat pertumbuhan di bidang industri, menciptakan lapangan kerja baru, menciptakan pertumbuhan di bidang ekonomi, meningkatkan kwalitas hidup manusia dan menampung kebutuhan masyarakat mejadi lebih cepat dan berkwalitas.

Jangka waktu Pasal 22, jangka waktu perlindungan hak paten adalah 20 tahun sejak tanggal penerimaan dan tidak dapat diperpanjang. Tanggal mulai dan berakhirnya hak paten dicatat dan diumumkan melalui media elektronik dan/ atau media non elektronik. Sedangkan paten sederhana berdasarkan Pasal 23 jangka 
waktu berlakunya adalah 10 tahun dihitung sejak tanggal penerimaan.dan tidak dapat diperpanjang. Tanggal dimuai dan berakirnya paten sederhana diumumkan melalui media elektroknik dan/ atau media non elektronik.

\section{Indonesia termasuk salah satu anggota dalam Konvensi Paris}

Konvensi Paris mengatur tentang hak milik perindustrian yang ditanda tangani oleh Paris pada tanggal 20 maret 1883 dan telah beberapakali mengalami revisi dan penyempurnaan. Revisi pertama di Brusse tanggal 14 November 1900, revis berikutya di Wasington tanggal 2 Juni 1911, di Denhaag 6 November 1925, di Lissabon 31 Oktober 1958, di Stockhom, 14 juli 1967 dan terakhir di Stockholm 2 oktober $1986 .{ }^{17}$ Perlindungan yang diberikan oleh konvensi ini adalah berkaitan perihal prosedur, prinsip-prinsip yang dijadikan pedoman wajib bagi negara anggota dan pihak patennya sendiri. Objek yang menjadi perlindungan menurut konvensi Paris adalah model rancang bangun, desain industri,, merek dagang, nama niaga dan indikasi dan sebutan asal. ${ }^{18} \quad$ Prinsip yang dianut oleh Konvensi Paris adalah persamaan hak nasional. Suatu negara anggota UNI berkewajiban untuk memperlakukan orang asing warga negara lain dari UNI sama dengan warga negaranya sendiri dalam hal paten. Perlakuan yang sama tidak hanya berlaku terbatas pada negara anggota konvensi tetapi bukan negara anggota pun yang berdomicili dinegara UNI atau mempunyai usaha industri atau komersil di negara UNI berhak atasnya untuk mendapat perlindungan.

Perlakuan semua hak juga berlaku atas semua kemudahan dan keuntungan yang diatur oleh hukum nasional bagi warga negara (Pasal 2 ayat (1) Konvensi Paris. Aturan ini tidak mengatur perlindungan secara timbal balik. ${ }^{19}$ Aturan nasional yang berkaitan dengan pengadilan adminstratif yurisdiksi diatur secara tersendiri. Ini berarti ada prosedur tertentu yang harus dipenuhi oeh orang asing juga dapat diterapkan pada orang asing yang juga merupakan warga negara anggota (Pasal 2 ayat (3).

Pasal 4 mengatur hak prioritas. Adanya hak prioritas, apabila permintaan suatu perlindungan hak milik perinduatrian telah didaftarkan oleh seseorang salah

\footnotetext{
${ }^{17} \mathrm{Ibid}, \mathrm{hlm} 308$

${ }^{18}$ Ibid

${ }^{19}$ Ibid
} 
satu negara angora Konvensi Paris, atas permintaan yang sama dapat di minta perlindungan dari semuan anggota konvensi. Permintaan tersebut akan dianggar didaftarkan apabila pada tanggal pendaftaran pertama, jangka waktu yang diberikan untuk hak prioritas selama 6 atau 12 bulan. $^{20}$ Negara Indonesia termasuk salah negara yang ikut dalam Konvensi Paris.

\section{Perlindungan Invensi Warga Negara Asing di Wilayah Indonesia}

Salah satu kelemahan negara sedang berkembang termasuknya Indonesia ketertinggalan dalam bidang teknologi, pada hal teknologi itu sangat penting sebagai sarana yang dibutuhkan dalam proses industri. Tidak ada kegiatan industri yang tidak membutuhkan teknologi dalam melakukan proses produksi dalam menghasilkan barang-barang. Negara berkembang cenderung sebagai pemakai teknologi yang diciptakan oleh negara-negara maju didunia. Peran teknologi sangat penting sekali untuk melakukan pembangunan di negara yang sedang berkembang untuk mensejahterakan masyarakatnnya.

Perkembang teknologi pada negara- negara menjadi perhatian bagi negara berkembang untuk dapat pengambil alihan teknologi yang digunakan untuk melakukan pembangunan di negara berkembang itu sendiri. Pengambil alihan itu tentu tidak dapat dilakukan begitu saja tanpa adanya adanya aspek hukum yang digunakan untuk melakukan pengambil alihan teknologi.

Dampak Indonesia ikut dalam konvensi Paten di Paris Perlindungan hukum paten tidak hanya diberikan kepada inventor nasional tetapi juga diberikan kepada inventor asing terhadap invensinya di wilayah Indoesia. Ketentuan hukum paten dalam konvensi Paris berlaku bagi negara yang mengikatkan diri dan bagi warga negara lain yang temuan paten ditemukan di dalam negara dan didaftarkan di negara keanggotan Konvensi Paris. Perlindungan hukum terhadap pemegang paten warga negara asing terhadap invensi patennya di wilayah Indonesia sama perlindung hukum yang diberikan kepada inventor nasional terhadap invensi patennya di wilayah Indonesia.

Indonesia sebagai salah satu negara sedang berkembang yang sangat membutuhkan teknologi dan alih teknologi dari investor asing, menjadi kewajiban negara untuk memberi perlindungan hukum terhadap invensi asing di wilayah di

\footnotetext{
${ }^{20}$ Ibid
} 
wilayah Indonesia agar inventor asing mau melakukan pendaftaran dan melaksanakan invensinya di wilayah Indonesia.

Berdasarkan Pasal 5 Undang Undang Nomor 13 tahun 2013 tentang Paten, invensi yang dapat diberikan paten adalah. Inventor asing yang melakukan pendaftaran dan melaksanakan invensinya di wilayah Indonesia, berlaku ketentuan hukum paten yang berlaku di Indonesia. Hak dan kewajiban Inventor asing terhadap invensinya di wilayah Indonesia diberikan hak eksklusif oleh negara untuk melaksanakan sendiri invensinya atau mengalihkan kepada pihak lain untuk melaksanakannya berdasarkan perjanjian lisensi dengan menerima imbalan berupa royalti.

Hak dari inventor asing terhadap invensi patenya di wilayah Indonesia adalah Pemegang paten memilik hak eskklusif untuk melaksanakan paten yang dimilikinya dan untuk melarang pihak lain yang tanpa persetujuannya antara lain: dalam hal paten produk: invensi asing digunakan sebagai alat dalam melakukan proses produksi yang menghasilkan suatu barang yang bernilai ekonomis yang kemudian dijual tidak hanya untuk keperluan dalam negeri akan tetapi juga dapat dilakukan ekspor yang merupakan pemasukan dari negara dari pajak.

Dalam hal paten proses, untuk melakukan proses produksi dalam industri dibutuhkan teknologi untuk menghasilkan barang yang bernilai ekonomis. Untuk melakukan proses produksi selain teknologi diperlukan sumber daya manusia yang akan mengerakan proses produksi, sehingga kehadiran teknologi yang digunakn untuk melakukan proses produksi akan membuka lapangan kerja, mengurangi angka pengangguran dan menciptakan pertumbuhan ekonomi masyarakat.

Perlindungan hukum terhadap paten warga negara asing di wilayah Indonesia, sama dengan Invetor nasional negara memberikan hak eksklusif terhadap paten warga negara asing di wilayah Idonesia. Hak eksklusif yang diberikan negara adalah pemegang paten warga negara asing dapat melaksanakan invensinya sendiri di wilayah Indonesia atau dialihkan kepada pihak lain berdasarkan perjanjian agar pihak lain juga mendapat manfaatnya ekonomi dari invensi patennya dengan kewajiban pihak lain untuk membayar royati sesuai perjanjian yang disepakati. 
Kehadiran paten warga negara asing sangat diharapkan oleh negara Indonesia karena akan terjadinya transfer teknologi, meningkatkan pertumbuhan ekonomi, membuka lapangan kerja, membuka daerah baru yang semula daerah yang terisolir menjadi daerah yang terbuka, maju dan berkembang serta meningkatkan investasi asing di wilayah Indonesia. Bagi negara Indonesia kehadiran invenstor asing dengan invensi patennya di Indonesia dapat memberikan dampak yang positif mengembangan sektor industri, perdagangan, perkebunan, pertanian dan membuka lapangan kerja. Pemerintah Indonesia lebih senang apabila inventor paten warga negara asing untuk mendaftarkan dan melaksanakan invensi patennya di Indonesia.

Indonesia sebagai negara berkembang yang membutuhkan teknologi dalam melakukan proses industri mengolah bahan baku menjadi bahan jadi dalam segala sektor kehidupan masyarakat. Kekayaan alam Indonesia yang melimpah dibutuhkan teknologi untuk mengolahnya. Kehadiran invensi paten warga negara asing seiring dengan kegiatan investasi yang dilakukan oleh investor asing di Indonesia diharapkan dapat mengolahkan sumberdaya alam yang berlimpah yang belum terolah dengan perkembangandan kemajuan teknologi menjadi sumber daya alam yang bernilai ekonomi, sehingga dapat mensejahterakan masyarakat dan memajukan bangsa.

\section{Manfaat Perlindungan Paten warga negara asing di wiyah Indonesia}

Manfaat perlindungan paten warga negara asing di wilayah Indonesia adalah untuk mengalihkan tekonolgi dari negara maju kepada Indonesia sebagai negara berkembang. Negara maju lebih senang mengerjaan patennya di negaranya sendiri atau dinegara industri maju lainnya. Invensinnya kemudian dipasarnya di negara sedang berkembang, karena biaya produksinya lebih rendah, inventasi lebih menguntungkan, pemasaran lebih luas karena negara sedang berkembang termasuk Indonesia berpenduduk dengan jumlah yang besar. Efisien lebih tinggi akan menghasilkan keuntungan lebih besar jika hasil paten dilaksanakan di Indonesia.

Sedangkan bagi negara Indonesia paten itu lebih senang jika dilakukan di Indonesia karena untuk menambah nilai tambah bagi Indonesia sebagai negara sedang berkembang yaitu, pengunaan bahan baku diolah menjadi bahan jadi, 
menyerap tenaga kerja yang banyak yang akan menurunkan angka penganguran dan meningkatkan tenaga terampil di Indonesia karena adanya alih teknologi dari negara maju kenegara berkembang. Indoensia sebagai negara sedang berkembang membukan kesempatan bagi invenstor asing berinvestasi di Indonesia dengan melaksanakan invensi patennya di wilayah Indonesia. Invensi paten warga negara asing dibutuhkan dalam proses produksi, membuka lapangan kerja, mencegah penganguran dan menigkatkan pertumbuhan ekonomi masyarakat.

Kehadiran investor asing tidak hanya memberikan keuntungan kepada investor asing itu sendri tapi kita membutuhkan investor asing untuk melakukan perobahan dinegara daerah yang terisolir menjadi jad daerah terbuka, bahan baku yang belum terolah diolah menjadi bahan jadi yang mempunyai nilai ekonomis. Kehadiran investor dengan segala keahliannya dan profesionalisme yang dimiliki kemudian ditunjang teknologi yang mereka miliki membawa pembaharuan dan perkembangan dalam masyarakat. Investor asing mengolah bahan bahan baku menjadi bahan jadi dalam proses produksi didukung oleh teknologi. Kemajuan teknologi sangat dibutuhkan dalam pembangunan. Untuk meningkatkan kreatifitas investor berinvestasi di Indonesia dengan mengunakan teknogi diharapkan dapat membawa perubahan dan perkembangan masyaratat dalam segala bidang kehidupan untuk mensejahterakan masyarakat dan memajukan bangsa dan negara. 


\section{PENUTUP}

\section{Kesimpulan}

1. Undang-Undang Paten tidak hanya memberikan perlindungan hukum terhadap paten nasional tetapi juga memberikan perlidungan hukum Inventor paten warga negara asing. Perlindungan hukum terhadap invensi paten warga negara asing di wilayah Indonesia sama perlindungan hukum terhadap invensi paten nasional.

2. Manfaat inventor asing terhadap invensi paten di wilayah Indonesia adalah Indonesia sebagai negara berkembang sangat membutuhkan sekali alih teknologi dari negara maju yang digunakan dalam proses produksi mengolah bahan baku menjadi bahan, meningkatkan investasi, menyerap tenaga kerja, meningkatkan pembangunan dan mensejahterakan masyarakat dan menambah tenaga kerja terampil.

\section{Saran}

1. Indonesia sebagai negara yang sedang berkembang membutuhkan teknologi untuk mengolah bahan baku menjadi bahan jadi. Dalam melakukan proses produksi dapat dilepaskan dari peran teknologi, oleh sebab itu negara kita sangat membutuhkan invenstor asing berinvestasi di Indonesia dengan mengunakan teknologi yang digunakan dalam dunia industri.

2. Untuk memberi rasa aman, nyaman dan meningkatkan minat investrot asing berinvestasi di negara Indonesia negara berkewajiban untuk neningkatkan perlindungan hukum terhadap invesi paten warga negara asing di Indonesia dalam rangka untuk meningkatkan pertumbuhan ekonomi dan pembangunan bangsa dan negara menuju masyarakat yang sejahtera. 


\section{DAFTAR PUSTAKA}

\section{Buku}

Abdul Kadir Muhammad, Kajian Hukum Ekonomi Hak Kekyaan Intelektual, Bandung : Citra Aditya Bakti, 2007

Ok. Saidin, Aspek Hukum Hak Kekayaan Intelktual, Jakarta: PT Rajagrafindo Persada:, 2013

Peter Mahmod Marzuki, Penelitian Hukum, Cetakan Kesembilan, Jakarta: Prenadamedia Group, 2014

Soejono Soekanto, Pengantar Penelitian Hukum, Cetakan Ketiga, Jakarta:: UIPress), 1986

Subekti dan R Tjiprosudibio, Kitab Undang-Undang-Undang Hukum Perdata, Cetakan ke-10, Jakarta: Pradnya Paramita, 2003

Subekti, Pokok-Pokok Hukum Perdata, Cetakan ke -20, Jakarta: PT Intermasa, 1985

\section{Undang-Undang}

Undang-Undang Hak Cipta, Paten dan Merek, Bhuana Ilmu Komputer Kelompok Gramedia, Jakarta 2017

Undang-undang Nomor 13 Tahun 2016 tentang Paten

\section{Internet}

http://berinovasi.com/2017/10/17/apa-saja-contoh-hak-paten, diakses tanggal 31 Maret 2019 